\title{
Septicaemia models using Streptococcus pneumoniae and Listeria monocytogenes: understanding the role of complement properdin
}

\author{
Aline Dupont • Fatima Mohamed · Nur'Ain Salehen · Sarah Glenn · Lorenza Francescut • Rozita Adib • \\ Simon Byrne • Hannah Brewin · Irina Elliott · Luke Richards • Petya Dimitrova · Wilhelm Schwaeble • \\ Nina Ivanovska $\cdot$ Aras Kadioglu $\cdot$ Lee R. Machado $\cdot$ Peter W. Andrew $\cdot$ Cordula Stover
}

Received: 17 June 2013 / Accepted: 18 December 2013 / Published online: 12 April 2014

(C) The Author(s) 2014. This article is published with open access at Springerlink.com

\begin{abstract}
Streptococcus pneumoniae and Listeria monocytogenes, pathogens which can cause severe infectious disease in human, were used to infect properdin-deficient and wildtype mice. The aim was to deduce a role for properdin, positive regulator of the alternative pathway of complement activation, by comparing and contrasting the immune response of the two genotypes in vivo. We show that properdin-deficient and wildtype mice mounted antipneumococcal serotype-specific IgM antibodies, which were protective. Properdin-deficient mice, however, had increased survival in the model of streptococcal pneumonia and sepsis. Low activity of the classical pathway of complement and modulation of $F c \gamma R 2 b$ expression appear to be pathogenically involved. In listeriosis, however, properdin-deficient mice had reduced
\end{abstract}

Aline Dupont, Fatima Mohamed and Nur'Ain Salehen have contributed equally to this paper.

Electronic supplementary material The online version of this article (doi:10.1007/s00430-013-0324-z) contains supplementary material, which is available to authorized users.

A. Dupont · F. Mohamed - N. Salehen - S. Glenn - L. Francescut · R. Adib · S. Byrne $\cdot$ H. Brewin · I. Elliott · L. Richards ·

W. Schwaeble $\cdot$ A. Kadioglu $\cdot$ P. W. Andrew $\cdot$ C. Stover $(\square)$

Department of Infection, Immunity and Inflammation, Maurice

Shock Medical Sciences Building, University of Leicester,

University Road, Leicester LE1 9HN, UK

e-mail: cms13@le.ac.uk

P. Dimitrova $\cdot$ N. Ivanovska

Department of Immunology, Institute of Microbiology, Bulgarian

Academy of Sciences, Sofia, Bulgaria

L. R. Machado

Department of Genetics, College of Medicine, Biological

Sciences and Psychology, University of Leicester, Leicester, UK survival and a dendritic cell population that was impaired in maturation and activity. In vitro analyses of splenocytes and bone marrow-derived myeloid cells support the view that the opposing outcomes of properdin-deficient and wildtype mice in these two infection models is likely to be due to a skewing of macrophage activity to an M2 phenotype in the properdin-deficient mice. The phenotypes observed thus appear to reflect the extent to which M2or M1-polarised macrophages are involved in the immune responses to $S$. pneumoniae and L. monocytogenes. We conclude that properdin controls the strength of immune responses by affecting humoral as well as cellular phenotypes during acute bacterial infection and ensuing inflammation.

Keywords Complement $\cdot$ Mouse model $\cdot$ Bacterial infection $\cdot$ Dendritic cells $\cdot$ Macrophages $\cdot \mathrm{Fc}$ receptor

\section{Introduction}

Complement is an integral component of the antibacterial immune response. Its importance lies in its ability to recognise pathogen-associated molecular patterns, bound natural antibodies, charge clusters $[1,2]$ and hydrolysed C3. This recognition is translated into a sequential, tightly controlled activation of serine proteases using enzyme complexes, so-called convertases. $\mathrm{C} 4 \mathrm{~b} 2 \mathrm{~b}$ is the C3-converting enzyme of the classical and lectin pathways, whereas $\mathrm{C} 3 \mathrm{bBb}$ cleaves more $\mathrm{C} 3 \mathrm{~b}$ from $\mathrm{C} 3$ as part of alternative pathway activation. The alternative pathway, in addition, amplifies the activity of complement. By the addition of nascent $\mathrm{C} 3 \mathrm{~b}$ to the enzyme complexes, their substrate specificity for $\mathrm{C} 3$ changes to target $\mathrm{C}$, generating $\mathrm{C} 5 \mathrm{a}$, a potent anaphylatoxin and $\mathrm{C} 5 \mathrm{~b}$, the 
initiator of assembly in the target membrane of the membrane attack complex. While in the immediate response, crosstalk with coagulation and kininogen has been identified $[3,4]$, complement in the adaptive immune response co-determines the phenotypes of dendritic cells and $\mathrm{T}$ cells [5]. Properdin stabilises the C 3 and C5 convertases, extending their enzymatic half-lives. Its relative importance in mouse models of sepsis and non-septic shock has been documented using genetically engineered properdin-deficient mice [6, 7]. Hereditary human properdin deficiency, possibly in epistasis with certain immunoglobulin allotypes, predisposes to meningococcal septicaemia [8].

While formation and insertion of the membrane attack complex are efficient against gram-negative organisms, encapsulated organisms activate complement in the nonimmune host by binding of natural antibodies of the IgMtype [9]. In vitro, C3b deposition on the capsular pneumococcal serotype 2 strain D39 is mediated mainly by recognition of C1q to bound natural IgM, with some contribution by the alternative pathway of complement, consistent with the idea that the latter provides an amplification loop for increased $\mathrm{C} 3 \mathrm{~b}$ deposition [10]. In vivo, mice deficient in classical pathway activity $(\mathrm{C} 1 \mathrm{q}$ deficient $[\mathrm{P}$. Andrew, personal communication; [10]], C4 deficient [10]), in alternative pathway activity (Factor B deficient) [10], in lectin pathway activity (MASP-2 deficient, Ficolin A or Ficolin B deficient) $[11,12]$ or of C3 [13] was all significantly impaired in their survival of serotype 2 pneumococcal sepsis at $72 \mathrm{~h}$ compared to wildtype controls.

The alternative pathway is activated on the surface of Listeria monocytogenes [[14]; and own data]. Complement C5 is necessary to limit the number of viable $L$. monocytogenes retrieved from mouse organs after intravenous infection [15], most likely via intact chemotaxis and macrophage activation [16]. Complement receptors are known to be specifically involved in the uptake of $L$. monocytogenes by liver-resident Kupffer cells (CRIg) [17] and in the early phase of granuloma formation (CR3, which is CD11b/CD18 integrin) [18-20] in mouse models of listeriosis.

While natural antibodies provide protection against pneumococcal sepsis in mice [21], murine listeriosis is seen as a gold standard to assess cellular immunity [22]. This study investigates the role of properdin in gram-positive septicaemia by studying the phenotype of properdin-deficient mice and their wildtype controls in models of infection with $S$. pneumoniae and L. monocytogenes. Risk groups for these infections are as follows: for $S$. pneumoniae the very young and the elderly, and for $L$. monocytogenes, pregnant women and the immune compromised.

\section{Materials and methods}

Mice

Age-matched properdin-deficient and wildtype mice (C57B1/6 background) were taken from the colony generated and maintained at the University of Leicester (812 weeks old) [6]. Experiments were performed in accordance with UK Home Office regulations and institutional ethical approval.

Pneumococcal infection models

Streptococcus pneumoniae serotype 2, strain D39, was passaged in MF1 mice as standard procedure to maintain virulence. For infection, mice were anaesthetised with $2.5 \%(\mathrm{v} / \mathrm{v})$ fluothane (AstraZeneca, Macclesfield, UK) over oxygen (1.5-2 1/min), and pneumococcal suspension $\left(1 \times 10^{6} \mathrm{CFU}\right.$ in PBS, $\left.50 \mu \mathrm{l}\right)$ was administered intranasally (i.n. model). Intravenous infections were administered via the tail vein using the same dose (100 $\mu$ l i.v. model). Dose concentration was confirmed by plating on blood agar. Mice were monitored for signs of illness throughout the 7 days of the experiment and culled before reaching the endpoint of severely lethargic. This timepoint was recorded as the survival time. Mice alive at 7 days post-infection were deemed to be survivors. Vaccination with Pneumovax was performed by single intraperitoneal (i.p.) injection as described [23].

Determination of viable pneumococcal counts in lung homogenates and blood

Approximately $30 \mathrm{~min}, 6,24$ and $48 \mathrm{~h}$ after i.n. infection, mice were anaesthetised with $2.5 \%$ (v/v) fluothane, and blood was collected by cardiac puncture. Mice were culled, and lungs were collected into $10 \mathrm{ml}$ PBS and homogenised using an Ultra-Turrax T8 homogeniser (IKA-Werke, Germany). After i.v. infection, blood samples were collected from a tail vein at 24, 48 and $72 \mathrm{~h}$. Viable counts from each homogenate and blood sample were determined by serial dilution using blood agar (Oxoid) containing $5 \%(\mathrm{v} / \mathrm{v})$ defibrinated horse blood and overnight incubation in an anaerobic jar at $37^{\circ} \mathrm{C}$. The colonies showed typical morphology for $S$. pneumoniae and $\alpha$-hemolysis.

\section{Pulmonary C3 activation}

Lung homogenates from control and infected mice were analysed by Western blot using HRP-conjugated goat antimouse C3 (ICN pharmaceuticals Inc.), and the density of bands corresponding to the $\mathrm{C} 3$ activation products was measured. 
IgM, anti-PPS2 IgM, C3 and C4c ELISA

Bloods were collected under terminal anaesthesia by cardiac puncture. Sera from infected and control mice $(S$. pneumoniae model) were stored in aliquots at $-80{ }^{\circ} \mathrm{C}$ until required. Sandwich ELISAs were used to determine $\operatorname{IgM}$ (Bethyl Laboratories, Universal Biologicals Ltd., Cambridge UK) and total C3 levels (Immunology Consultants Laboratory Inc, Immune Systems Ltd., Paignton UK). To determine antipolysaccharide 2 IgM antibodies, plates were coated with purified serotype 2 pneumococcal polysaccharide (ATCC, Middlesex, UK) [24] and serum was added (1:300 dilution). Importantly, serum samples were preabsorbed $\left(37^{\circ} \mathrm{C}, 1 \mathrm{~h}\right)$ with purified pneumococcal cell wall polysaccharide (CWPS Statens Serum Institute, Denmark; $5 \mu \mathrm{g} / \mathrm{ml}$ ) to neutralise antibodies against cell wall polysaccharide before antibodies to PPS were detected using the antigen capture ELISA. C4c levels were determined using a previously described method [25].

\section{TNF- $\alpha$ levels}

A bioassay was performed using actinomycin sensitised L929 indicator cells, and levels were expressed in relation to a TNF- $\alpha$ standard (Peprotech EC Ltd., London).

\section{Listeria infection model}

Listeria monocytogenes serovar 1/2a, strain EGD-e (obtained from American Type Culture Collection) was passaged in $\mathrm{C} 57 \mathrm{~B} 1 / 6$ mice. $1 \times 10^{6} \mathrm{CFU}$ in PBS were injected in a tail vein $(100 \mu \mathrm{l})$. The number of viable, inoculated bacteria was determined by colony counts. The mice were monitored for signs of illness and culled before reaching a lethargic state. Mice alive at $96 \mathrm{~h}$ were considered to have survived the infection.

Determination of numbers of viable counts of L. monocytogenes in liver

Mice were culled, and livers were homogenised in $10 \mathrm{ml}$ PBS or $\mathrm{dH}_{2} \mathrm{O}$ as above. The numbers of CFU/g of liver tissue were determined by plating serial 10 -fold dilutions of homogenates on BHI-agar plate $\left(37^{\circ} \mathrm{C}, 24 \mathrm{~h}\right)$. The colonies showed typical morphology (small, round colonies with a bluish-green sheen when viewed by obliquely transmitted light).

\section{IFN $\gamma$ ELISA and nitric oxide measurement}

Bloods were collected under terminal anaesthesia by cardiac puncture. Sera were prepared from infected and control mice (L. monocytogenes model) and stored at $-80{ }^{\circ} \mathrm{C}$.
Murine IFN- $\gamma$ ELISA Development Kit was used according to the manufacturer's instructions (Peprotech). Nitric oxide production was measured using Griess Reagent kit (Promega, Wisconsin, USA).

Differentiation of dendritic cells and macrophages from mouse bone marrows

Bone marrow cells were prepared using standard methodology by flushing tibias and femurs with PBS using a $0.45 \mathrm{~mm}$ syringe. The supernatant, after sedimentation of debris, was centrifuged, and erythrocytes were lysed using a hypotonic solution. After neutralisation, cells were seeded at $2 \times 10^{6} / \mathrm{ml}$ in the presence of IL-4 and GM-CSF (each $10 \mathrm{ng} / \mathrm{ml}$; Peprotech). After 7 days, non-adherent cells were separately collected from those cells, which became adherent under these conditions. Both populations were used separately for in vitro infection in antibiotic free complete culture medium (RPMI 1640, $10 \%$ (v/v) FCS) with unpassaged, washed L. monocytogenes (at a multiplicity of infection, or MOI, of 0.2) in mid exponential growth phase, following the method described in a previous study [26].

\section{Cyclic amplification analyses}

cDNA was transcribed from $1 \mu \mathrm{g}$ total RNA prepared from cells or tissues using First Strand synthesis kit (Invitrogen). Gene-specific amplification using SensiMix SYBR kit (Bioline Reagents Ltd., London) was analysed with Rotor-Gene 6000 (Corbett Life Science) and expressed in relation to the housekeeping gene using the $\triangle \triangle \mathrm{CT}$ method. Primer sequences for this were mouse FcgR2b: 5'-CTGAGGCTGAGAATAC GATC-3' and 5'-GTGGATCGATAGCAGAAGAG-3'; for mouse FcgR4: 5'-GTGACCCTCAGATGCCAAGGC- ${ }^{\prime}$ and $5^{\prime}$-TGGATGGAGACCCTGGATCGC- ${ }^{\prime}$, for mouse $\beta$-actin: $5^{\prime}$-GTGGGCCGCTCTAGGCACCAA-3' and $5^{\prime}$-CTCTTT GATGTCACGCACGATTTC-3', for mouse IL-17A 5'-GGCT GACCCCTAAGAAACC- $3^{\prime}$ and 5'-CTGAAAATCAATAG CACGAAC- $3^{\prime}$. Annealing temperatures were $60,68,55$ and $53{ }^{\circ} \mathrm{C}$, respectively.

Oligonucleotides used for standard amplification of murine transcripts for TLR2, CD11b and C3 (annealing temperature $55^{\circ} \mathrm{C}$ ) were $5^{\prime}$-GGCCAGGTTCCAGTTTTCAC- $3^{\prime}$ and 5'-GGAACAACGAAGCATCTGGG-3'; 5'-GATGGTGTC GAGCTCTCTGCG-3' and $5^{\prime}$-TTGTCTCAACTGTGATG GAGCA-3'; 5'-GAATACGTGCTGCCCAGTTT- ${ }^{\prime}$ and 5'-TG AGTGACCACCAGCACTTT-3', respectively.

Flow cytometric analyses

To quantify the phagocytic uptake of $S$. pneumoniae D39 by splenic macrophages, extracellular fluorescence was quenched with $0.2(\mathrm{w} / \mathrm{v}) \%$ trypanblue prior to flow 
cytometry. To prepare the labelled bacteria, S. pneumoniae D39 were grown in broth (stationary, $37^{\circ} \mathrm{C}$ ), and $10^{9}$ bacteria/ml were resuspended in $0.1 \mathrm{mg} / \mathrm{ml}$ FITC (SigmaAldrich, 0.1 $\mathrm{M} \mathrm{NaHCO}_{3} \mathrm{pH}$ 9.0). After $60 \mathrm{~min}$ at room temperature, bacteria were spun and washed in PBS until the supernatant no longer was yellow. Splenic cell suspensions were prepared from a pool each of two properdindeficient and wildtype mice, and adherent cells were incubated in the presence of genotype-matched serum with labelled S. pneumoniae for $1 \mathrm{~h}$ prior to analysis.

To characterise the dendritic cell phenotype after infection with heat-killed L. monocytogenes (MOI 0.2), surface expressions of CD11c and CD40, CD80, CD86 or MHCII, respectively (BD Biosciences Pharmingen, Oxford, UK), were analysed. Positive staining was compared with the relevant isotype controls (mouse IgG FITC or PE labelled, BD Biosciences Pharmingen). Compensation for different spectra was performed.

To investigate the level of $\mathrm{Fc} \gamma \mathrm{R} 2 \mathrm{~b}$ expression, splenocytes were prepared from properdin-deficient and wildtype mice, infected overnight with heat-killed L. monocytogenes (MOI 20) and analysed with PE-labelled B-cell-specific rat antimouse CD45R/B220 and FITC-labelled rat antimouse CD16/CD32 (Fc $\gamma \mathrm{III} / \mathrm{II}$ receptor) (2.4G2) (BD Pharmingen).

Events were acquired using Becton-Dickinson FACS Scan and CellQuest pro software.

\section{Statistical analyses}

Survival curves were compared using the log rank test. Other data were analysed using $t$ tests. The difference in sequentially measured CFU in blood from infected mice was analysed by Mann-Whitney $U$ test.

\section{Results}

Properdin is dispensable for protective immunity to Streptococcus pneumoniae, but significantly contributes to demise in acute pneumococcal pneumonia and sepsis

An intact complement system is necessary in the immune response to encapsulated microorganisms [27]. To investigate the response of properdin-deficient mice to capsular polysaccharides in comparison with wildtype mice, mice were immunised i.p. with Pneumovax, a 23-valent pneumococcal polysaccharide vaccine. Natural antipolysaccharide IgM antibodies were detectable before vaccination. At the end of the four-week experimental period, both genotypes had raised an IgM antiserotype 2 capsular polysaccharide response (Fig. 1a). To determine whether they were protective, immunised mice were challenged with serotype
$2 S$. pneumoniae by i.n. inoculation, which normally proceeds from bronchopneumonia to sepsis within 24-48 h. While both genotypes immunised with Pneumovax were protected in the challenge infection (Fig. 1b), localising pneumococci to alveolar macrophages (Fig. 1c), the survival of the non-immunised mice infected in parallel was significantly different (Fig. 1b): while wildtype mice succumbed rapidly, with $2 / 5$ alive at the experimental endpoint of 7 days, $4 / 5$ properdin-deficient mice remained alive. To confirm this finding, additional groups of naïve mice were infected with an independently prepared stock of passaged S. pneumoniae, and again, properdin-deficient mice showed significantly greater survival compared to wildtype mice ( $8 / 10$ vs $4 / 10)$ (Fig. S1A). They also had significantly milder disease at $24 \mathrm{~h}$ (Fig. S1B). Individual mice were sampled at various timepoints p.i. and viable pneumococcal counts in lungs and blood determined; while wildtype mice appeared to control bacterial numbers in lungs at $48 \mathrm{~h} \mathrm{com-}$ pared to $24 \mathrm{~h}$, as expected for mice of this genetic background, properdin-deficient mice failed to do so (Fig. 2a). In fact, properdin-deficient mice had the highest bacterial count in blood at $48 \mathrm{~h}$ (Fig. 2b), from where bacteria may reseed the lungs (personal communication, A. Kadioglu). The differential count of neutrophils in lung homogenates prepared from wildtype and properdin-deficient mice at all timepoints was not significantly different from each other though relative numbers peaked at $24 \mathrm{~h}$. At this timepoint, sublocalisation of neutrophils was investigated histologically (parenchymal vs tethered). There was no difference between the infected genotypes, though parenchymal neutrophils expectedly were elevated compared to controls. The percentage of capillary neutrophils tethered to the endothelium was also comparable between the infected genotypes (Suppl. Table 1). Histological examination of lung sections at this timepoint showed regional leukocytic infiltrations, hyperaemia and thickening of interalveolar spaces, all typical signs of pneumonia. Serum C3 levels and $\mathrm{C} 3$ activation fragments in the lung were increased over baseline for both genotypes and were higher for properdin-deficient than for wildtype mice at $48 \mathrm{~h}$ (supplementary Table 2), when the viable count was highest in blood and lungs of properdin-deficient mice.

Previously, activation of the classical pathway of complement was shown to be important in murine survival of S. pneumoniae [10]. Wildtype and properdindeficient mice showed a significant decrease in circulating IgM levels as early as $24 \mathrm{~h}$ (Table 1), likely to be due to binding to $S$. pneumoniae and sequestration from the fluid phase. $\mathrm{C} 4 \mathrm{c}$, a product of complement activation, was significantly increased in the sera from infected wildtype, but not in the sera from properdindeficient mice compared to their respective, comparable, baselines (Table 1), consistent with greater 
A
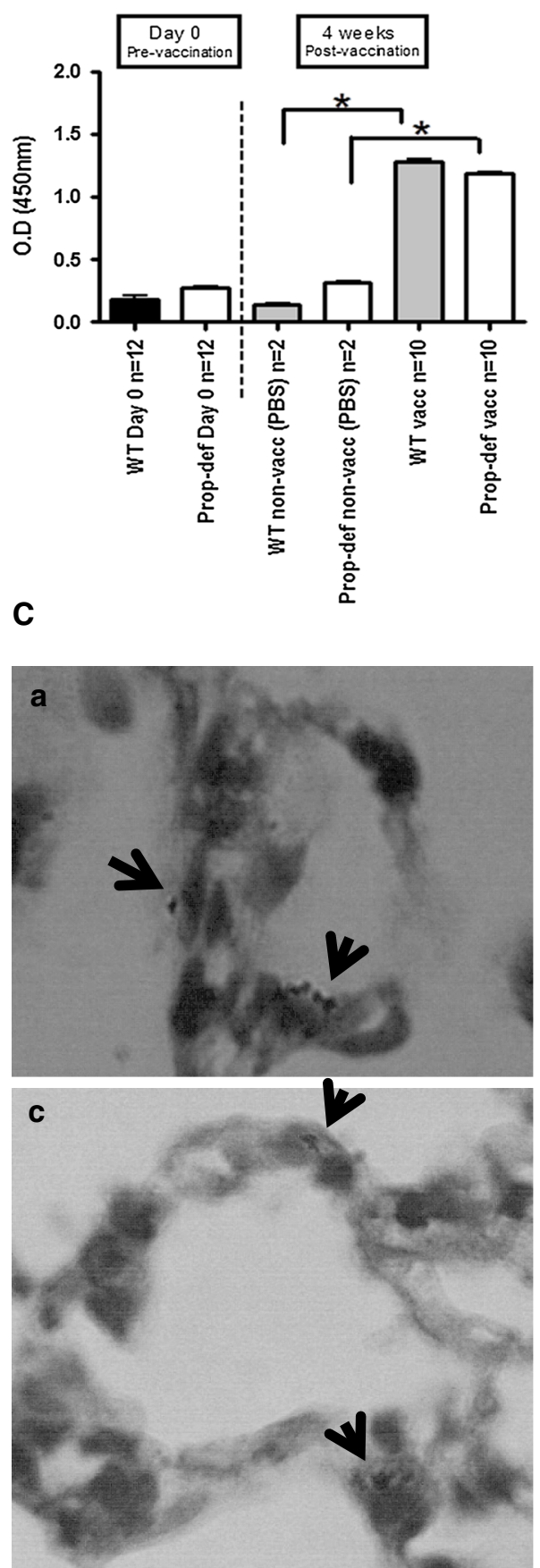

Fig. 1 Properdin-deficient mice in pneumococcal vaccination and infection model. a Generation of anticapsular polysaccharide type $2 \mathrm{IgM}$ antibodies after immunisation with Pneumovax: levels of IgM-specific antibodies responses to capsular polysaccharide type 2 after pre-absorption of sera with capsular wall polysaccharides (mean $\pm \mathrm{SD}$ ), pre- and post-vaccination. After vaccination with the polysaccharide vaccine, properdin-deficient and wildtype (WT) mice showed an increase in anticapsular type $2 \operatorname{IgM}$ antibodies $(p<0.05)$ compared to non-vaccinated (PBS injected) mice. Importantly, these levels were reached at week 1, consistent with [28]. b Pneumococcal pneumonia and sepsis in untreated and immunised mice. Wildtype mice are protected during intranasal challenge with $S$. pneumo-
B
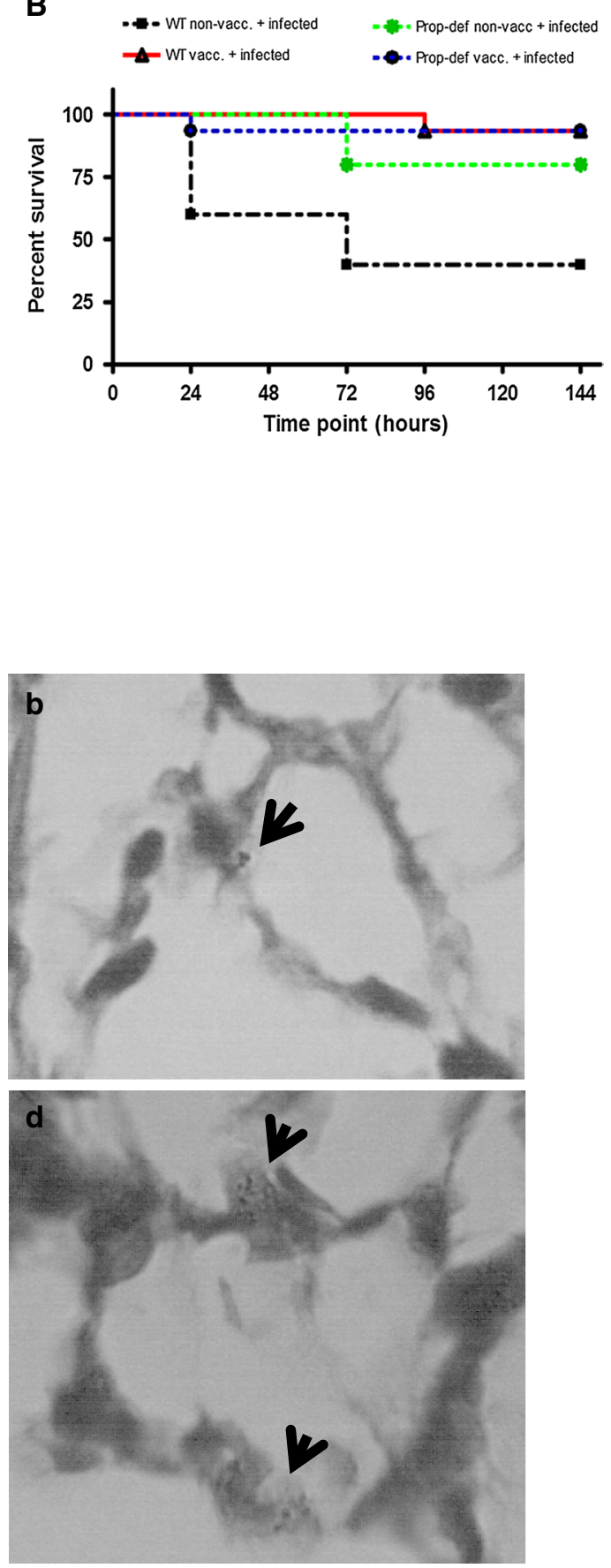

niae D39 (vaccination success), while properdin-deficient mice show greater survival independent of immunisation. The survival of infected properdin-deficient mice compared to infected wildtype mice is significantly better $(p<0.05)$. Viable counts were recovered from the bloodstreams of $2 / 5$ infected, non-vaccinated mice of either genotype, whereas in the vaccinated and challenged groups, viable counts were detected in only one of the properdin-deficient mice. c Representative images of cocci present in alveoli at the endpoint of the experiment (day 7). Lung sections ( $a$ non-vaccinated and infected $\mathrm{WT} ; b$ non-vaccinated and infected $\mathrm{KO} ; c$ vaccinated and infected WT; $d$ vaccinated and infected $\mathrm{KO}$ ) were stained with Wright's stain. $\times 100$ oil immersion 

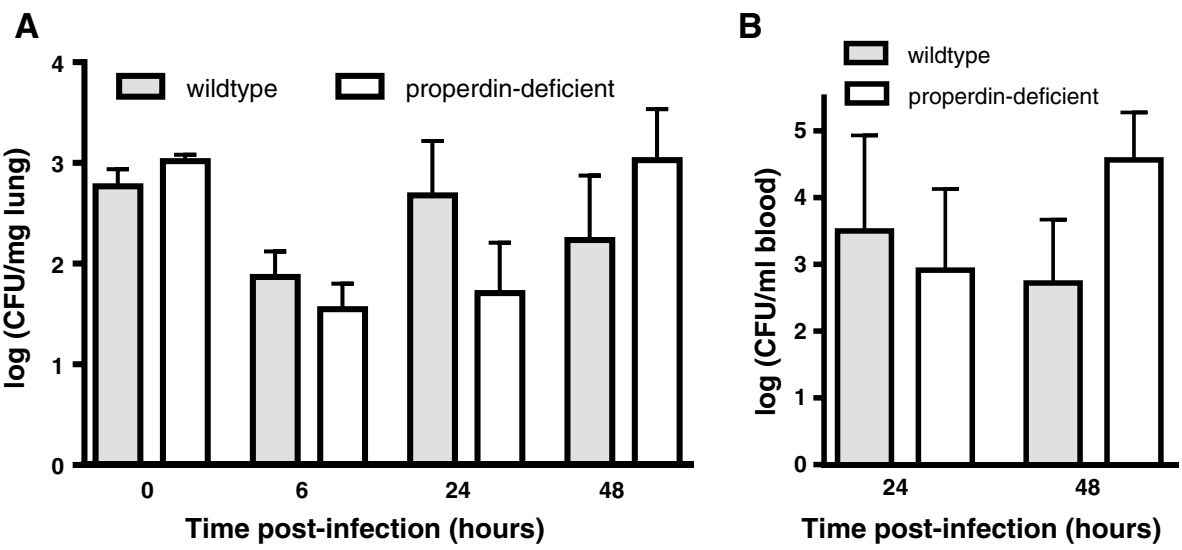

Fig. 2 Viable pneumococci in lungs and blood of infected properdin-deficient and wildtype mice. a Wildtype mice limited bacterial numbers in lungs at $48 \mathrm{~h}$ compared to $24 \mathrm{~h}$, while the numbers of viable bacteria were increased in properdin-deficient mice for these timepoints $(n=2$ for $\mathrm{t} 0,5-6$ for $\mathrm{t} 6 \mathrm{~h}, 4-5$ for $\mathrm{t} 24 \mathrm{~h}, 8-10$ for $\mathrm{t} 48 \mathrm{~h}$; \pm SEM). b Properdin-deficient mice have greater bacteremia than wildtype mice at $48 \mathrm{~h}(n=10$ each group, \pm SEM $)$
Table 1 Serum IgM and C4c levels in sera of properdindeficient and wildtype mice (uninfected and infected with S. pneumoniae)

\begin{tabular}{lccc}
\hline \multicolumn{1}{c}{$T_{0}$} & $T_{24 \mathrm{H}}$ & $T_{48 \mathrm{H}}$ \\
\hline Serum IgM levels $(n g / \mu l) \pm S D, * p<0.05($ compared to $0 H)$ & \\
Wildtype & $88.1 \pm 42.4(N=9)$ & $42.2 \pm 28^{*}(N=5)$ & $46.4 \pm 4.2 *(N=4)$ \\
Properdin-deficient & $84.1 \pm 47.9(N=10)$ & $45 \pm 18.9 *(N=5)$ & $52.8 \pm 8.1 *(N=5)$ \\
Serum C4c levels (semiquantitative, $\left.O D_{405} \pm S D\right), * p<0.05($ compared to $0 H)$ & \\
Wildtype & $1.6 \pm 0.2(N=3)$ & $1.9 \pm 0.5(N=5)$ & $2.4 \pm 0.2 *(N=4)$ \\
Properdin-deficient & $1.5 \pm 0.1(N=2)$ & $1.5 \pm 0.6(N=5)$ & $1.8 \pm 0.4(N=5)$ \\
\hline
\end{tabular}

complement activity in properdin-sufficient wildtype mice. In keeping with this, association of C3 to S. pneumoniae in vitro via the classical pathway was significantly higher after incubation with sera from wildtype than from properdin-deficient mice (Fig. 3a). To compare opsonophagocytosis in the two genotypes, splenocytes were isolated from wildtype and properdin-deficient mice and incubated for $1 \mathrm{~h}$ with S.pneumoniae previously incubated with a pool of sera from either wildtype or properdin-deficient mice (Fig. 3b, c). $S$. pneumoniae opsonised with serum from wildtype associated significantly more with splenocytes prepared from wildtype mice compared to the matched properdin-deficient experimental sample. As a consequence, splenocytes from wildtype mice released significantly more TNF- $\alpha$ compared to those from properdin-deficient mice after infection with $S$. pneumoniae. During intravenous infection with $S$. pneumoniae, the rate of bacterial growth from 24 to $72 \mathrm{~h}$ was the same in the two genotypes, but the bacterial burden was significantly higher in properdin-deficient mice (Fig. 3d).

Taken together, the experiments thus far revealed that in the presence of the alternative pathway amplification loop, anticapsular antibodies activate the classical pathway of complement and enhance phagocytosis and proinflammatory cytokine release, the extent of which was detrimental to the wildtype host, while in the absence of properdin, clinical signs of pneumococcal septicaemia were less severe, even though the viable counts recoverable from blood were higher than in wildtype mice.

Following a report that survival of pneumococcal sepsis was improved in the absence of the inhibitory Fc $\gamma \mathrm{R} 2 \mathrm{~b}$ receptor [29] —and others dealing with the crosstalk between complement and $\mathrm{Fc} \gamma \mathrm{R}$ expression [30, 31]-we investigated $\mathrm{Fc} \gamma \mathrm{R} 2 \mathrm{~b}$ expression in properdin-deficient and wildtype mice. The mRNA expression of Fc $\gamma$ R2b in spleen was reduced in properdin-deficient mice (Fig. S2A). After in vitro infection of splenocytes with $S$. pneumoniae, however, cells from wildtype mice decrease their expression while properdin-deficient cells show more abundant expression, supporting the pro-inflammatory phenotype in wildtype mice shown in Fig. 3c. The activating receptor Fc $\gamma \mathrm{R} 4$ (functionally antagonistic to $\mathrm{Fc} \gamma \mathrm{R} 2 \mathrm{~b}$ ), in contrast, is inversely expressed in wildtype and properdindeficient spleens (Fig S2B). To unequivocally demonstrate a difference in expression of $\mathrm{Fc} \gamma \mathrm{R} 2 \mathrm{~b}$ between wildtype and properdin-deficient mice, splenocytes from age- and sex-matched mice were analysed by flow cytometry for 


\section{A}

$\begin{array}{llll}\text { GVB }^{++} / & & \text {GVB }^{++} \\ \text {EGTA/Mg } & & \\ \text { WT } & \text { KO } & \text { WT } & \text { KO }\end{array}$
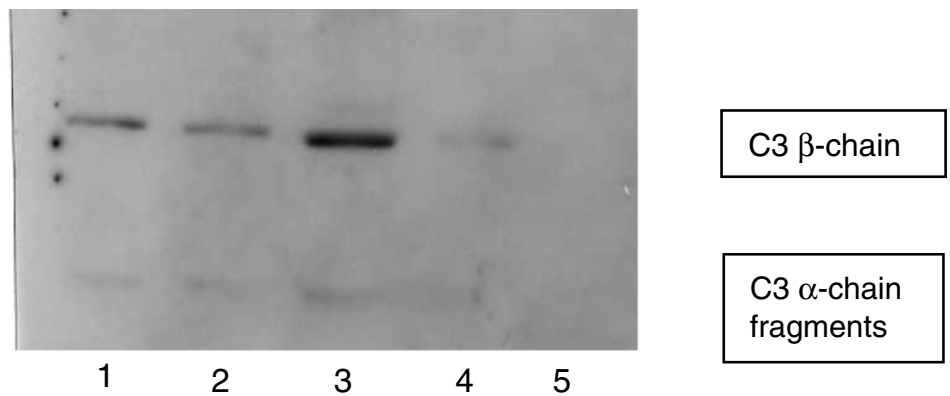

C3 $\alpha$-chain fragments

B

C
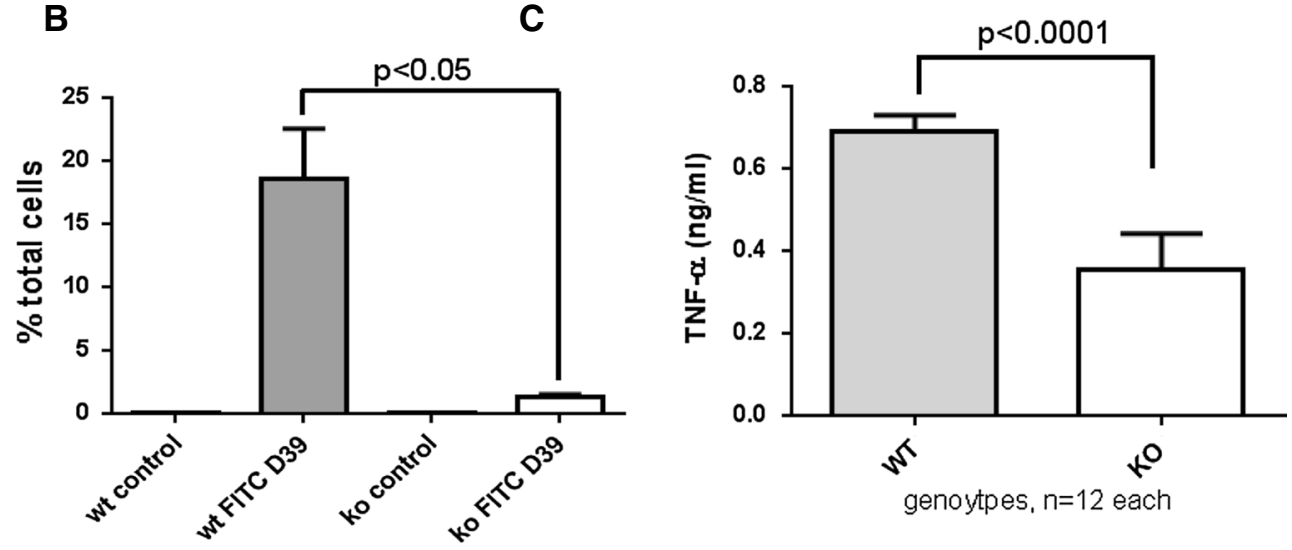

D

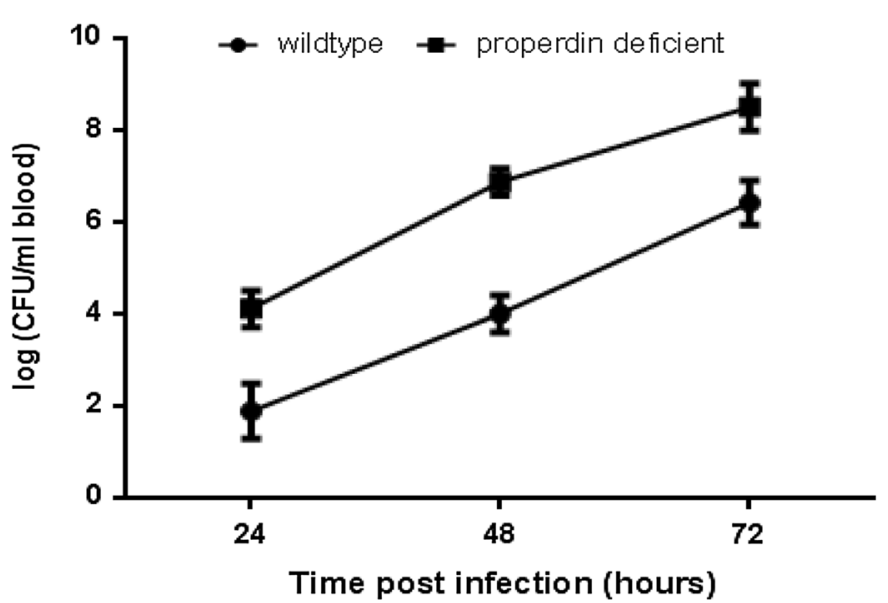

Fig. 3 Complement activation, phagocytosis and intravascular survival of $S$. pneumoniae D39. a C3 reactivity of separated bacterial pellets after incubation with mouse sera (pool $n=6$ ) under conditions favouring the alternative pathway $\left(\mathrm{GVB}^{++} / \mathrm{EGTA} / \mathrm{Mg}^{2+}\right)$ or classical pathway $\left(\mathrm{GVB}^{++}\right.$) activation, $37{ }^{\circ} \mathrm{C}, 30 \mathrm{~min}$ (Western blot); lane 5 shows specificity of rat antimouse C3 antibody (only D39, no serum). b Pools of 9 sera-matching each cell genotype were used to opsonise FITC-labelled $S$. pneumoniae before addition to respective mouse splenocytes for $1 \mathrm{~h}$. Flow cytometry was performed, while quenching extracellular signal with trypan blue (representative analysis of $n=2$ ). C After 24 h' infection of splenic macrophages with D39, there is decreased TNF- $\alpha$ production (measured using L929 assay) by splenocytes from properdin-deficient mice in the presence of properdin-deficient sera compared to wildtype cells with wildtype sera. d Both genotypes were injected i.v. with $10 \mathrm{e} 6$ D39 and bacterial counts $( \pm \mathrm{SEM})$ determined for each of 3 days from $n=5$ each genotype $(p<0.05)$ 
Fig. 4 Bone marrow-derived macrophages and dendritic cells infected with L. monocytogenes: cellular responses. a Intracellular viable counts were determined $24 \mathrm{~h}$ p.i., MOI 0.2 , after treatment of cells with $10 \mu \mathrm{g} / \mathrm{ml}$ gentamicin (dendritic cell population from wildtype compared to properdin-deficient mice: $p<0.005)$. b IFN- $\gamma$ released into the supernatant of infected cells $(24 \mathrm{~h})$ was measured by ELISA (dendritic cell population from wildtype compared to properdin-deficient mice: $p<0.01)$. c Nitric oxide release of infected cells $(24 \mathrm{~h}$ ) and controls, determined by the Griess reaction (dendritic cell population from wildtype compared to properdin-deficient mice: $p<0.01)$. Representative of two independent experiments set-up in triplicate

expression of $\mathrm{Fc} \gamma \mathrm{R} 2 \mathrm{~b}$. Because the available monoclonal antibodies recognise both $\mathrm{Fc} \gamma \mathrm{R} 2 \mathrm{~b}$ and $\mathrm{Fc} \gamma \mathrm{R} 3$, analysis was restricted to B lymphocytes, which only express the inhibitory Fc $\gamma$ R2b receptor. Again, properdin-deficient mice had reduced expression of Fc $\gamma$ R2b (Fig S2C).

Properdin shapes the dendritic cell phenotype

and contributes significantly to host survival of septicaemia in Listeria monocytogenes infection

Because infection with $S$. pneumoniae unexpectedly revealed a cellular phenotype of properdin deficiency (low Fc $\gamma$ R2b expression, decreased phagocytosis), mice were next analysed in in vitro and in vivo models using an intracellular pathogen, L. monocytogenes. As for S. pneumoniae, mouse serum was not bactericidal for L. monocytogenes (data not shown), which is consistent with the literature $[11,32]$.

Bone marrow-derived cells were differentiated in the presence of IL-4 and GM-CSF, yielding an adherent, macrophage-like and non-adherent, dendritic cell-like population [26]. Cells were infected with live L. monocytogenes. We found that both cell populations increased their mRNA expression for $\mathrm{C} 3$, the integrin CD11b and TLR2 (data not shown). Infected macrophage-like cells from wildtype released marginally more $\mathrm{TNF}-\alpha$ than those from properdindeficient mice when infected with live, not heat killed, Listeria (data not shown). Remarkably, however, the dendritic cell-enriched population from properdin-deficient mice had significantly lower intracellular Listeria compared with those from wildtype mice, while there was no difference in the intracellular burden for the adherent cell population from the two genotypes (Fig. 4a). Release of IFN- $\gamma$ from infected cells from properdin-deficient mice was lower compared to wildtype mice (Fig. 4b). Nitric oxide release was induced by infection, to the greatest extent in the dendritic cell-like population from wildtype mice (Fig. 4c). Electron microscopy was used to determine the subcellular localisation of L. monocytogenes. Consistent with the greater viable counts determined in the dendritic cell-like population from wildtype mice compared with those from properdin-deficient mice, there were more Listeria present in the vacuoles
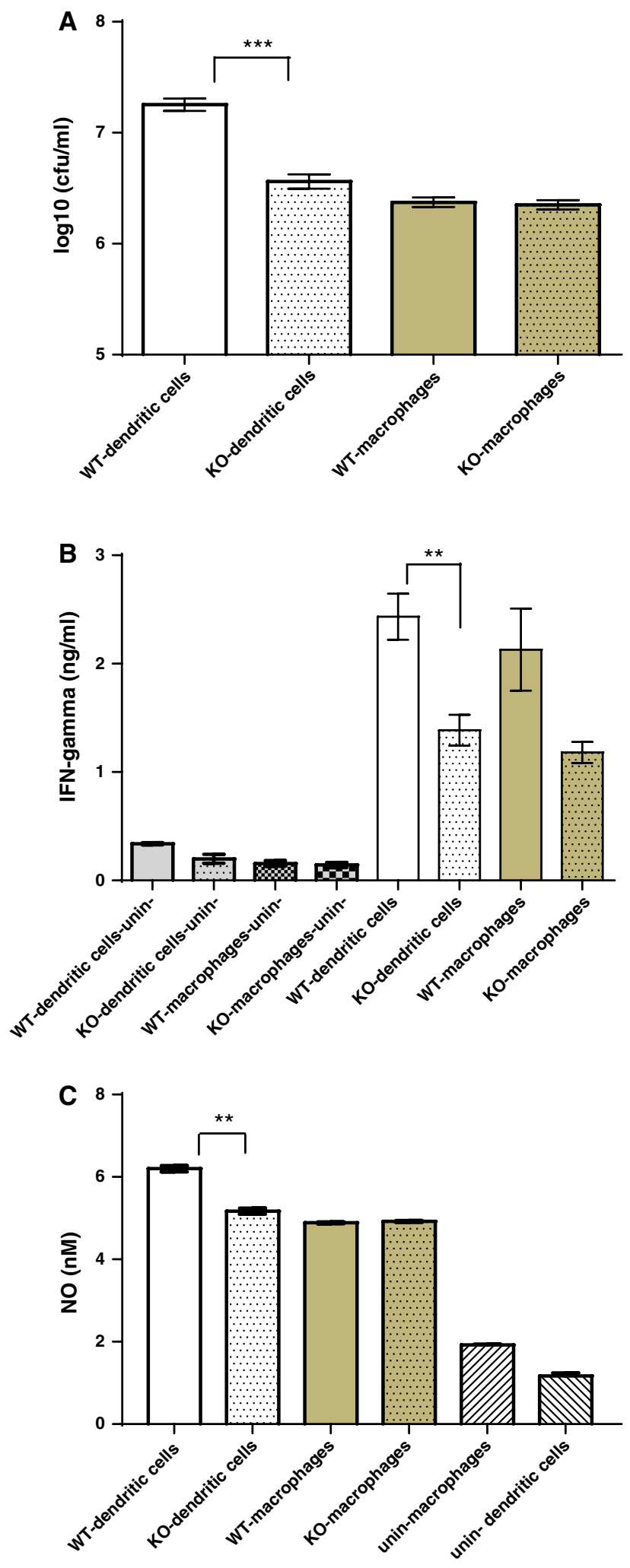

and cytosol of wildtype dendritic cell-like cells (Fig. 5a-f). Macrophage-like cells, however, did not follow this pattern. In contrast, there was a greater number of Listeria in the cytosol at $24 \mathrm{~h}$ than in vacuoles of cells from wildtype, not 
Fig. 5 Vacuolar and cytosolic localisation of L. monocytogenes in dendritic cells

(a-f) and macrophages ( $\mathbf{g}-\mathbf{l})$ from wildtype and properdindeficient mice (TEM) at $4 \mathrm{~h}$ (C,D,I,J) and $24 \mathrm{~h}(\mathbf{e}, \mathbf{f}, \mathbf{k}, \mathbf{l})$ p.i. Typical electron micrographs are juxtaposed to quantitative analysis of macrophages and dendritic cells from both genotypes (WT-DC $n=73$; KO-DC $n=12$ for $4 \mathrm{~h}$; WT-DC $n=11$; KO-DC $n=16$ for $24 \mathrm{~h}$, and WT-Mac $n=26$; KO-Mac $n=34$ for $4 \mathrm{~h}$; WT-Mac $n=5$; KO-Mac $n=16$ for $24 \mathrm{~h}$ ). Note the overall increase in bacteria at 24 h. $* p<0.05 ; * * p<0.05$ by unpaired $t$ test; variables are significantly different ( $F$ test) for analyses of $\mathbf{c} / \mathbf{d}, \mathbf{e} / \mathbf{f}, \mathbf{k} / \mathbf{l}$
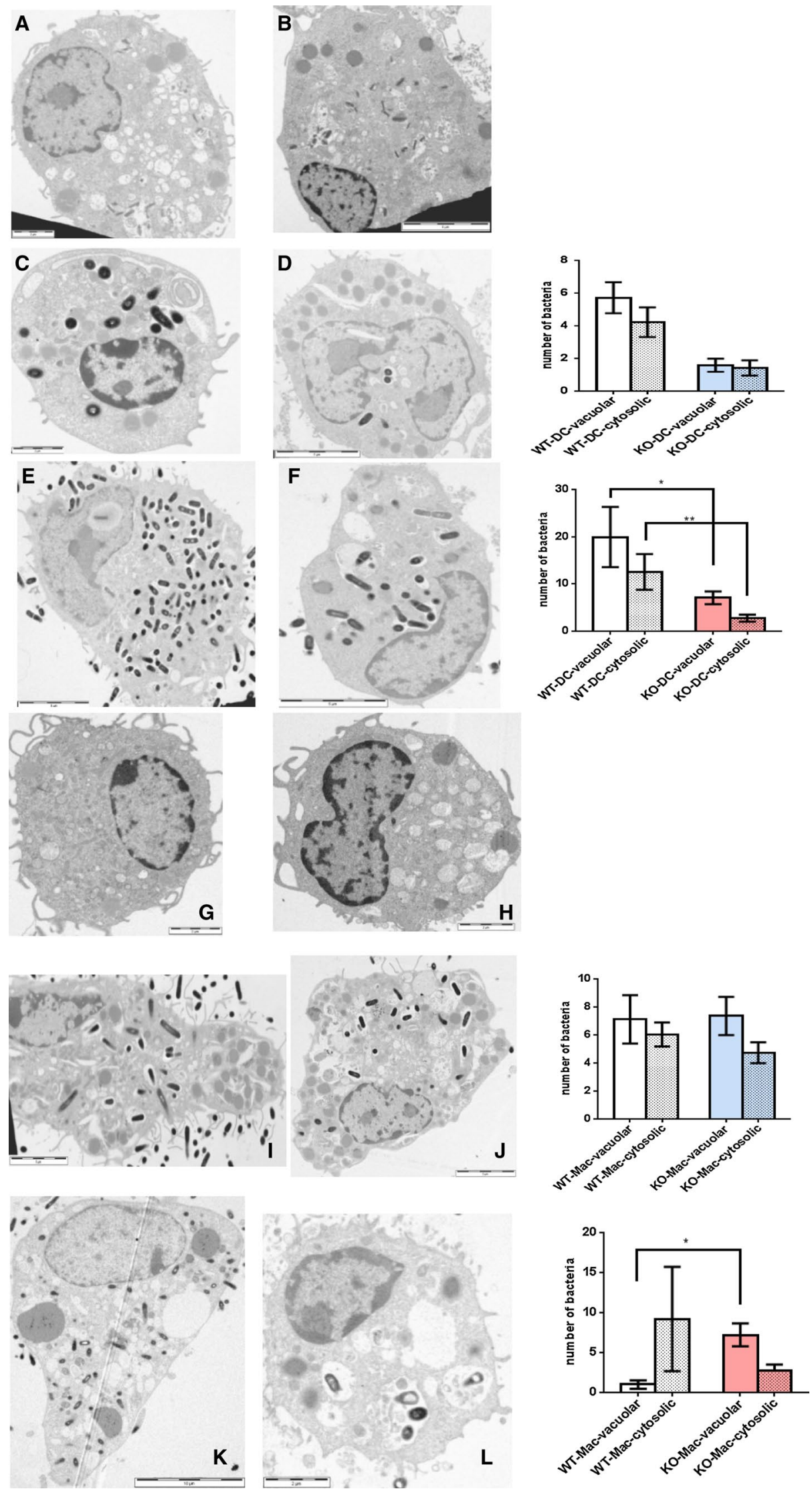

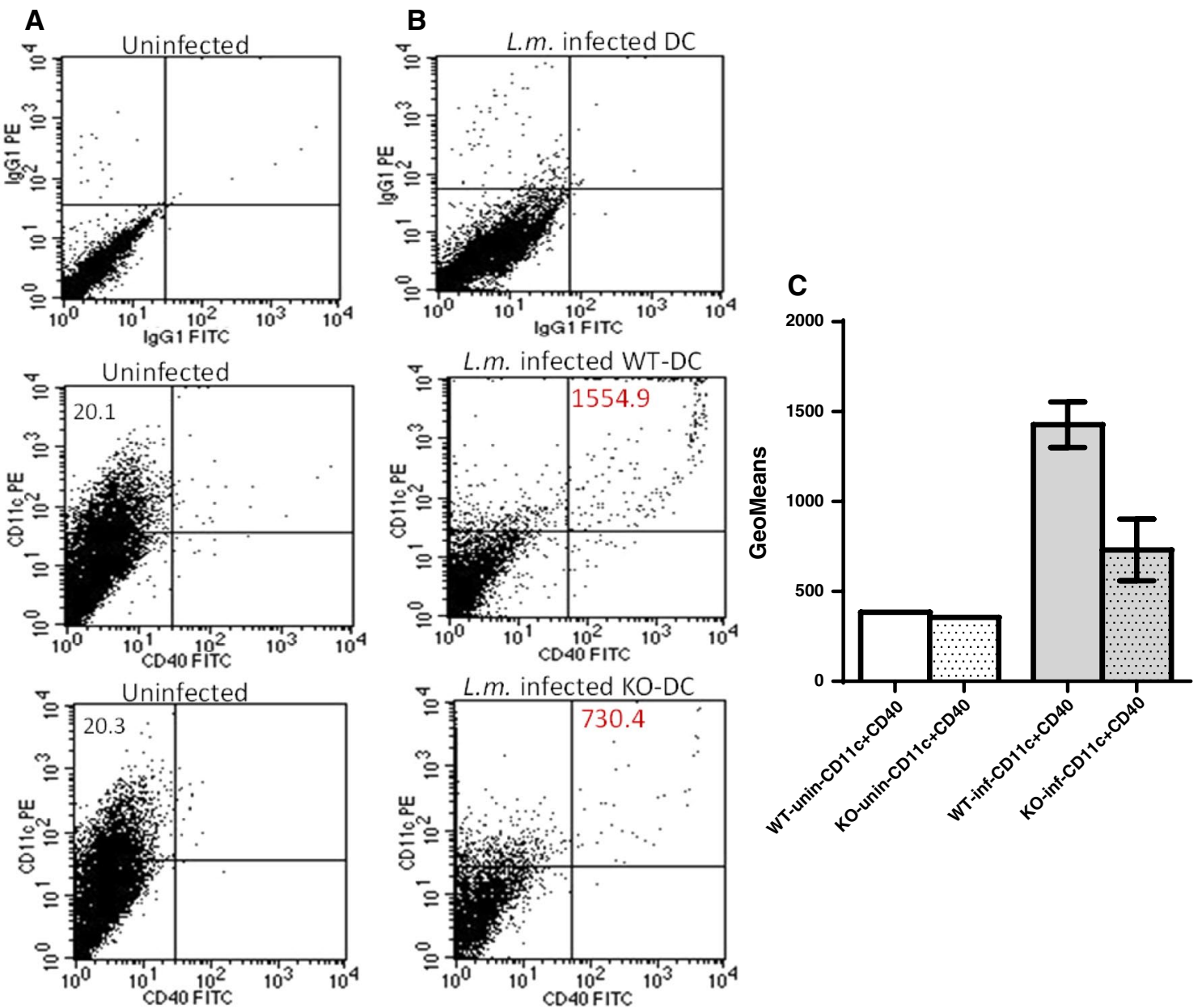

Fig. 6 Surface staining for CD40 and CD11c. a Top isotype controls; middle and bottom analysis of uninfected non-adherent cell population purified from bone marrow of wildtype and properdin-deficient mice showing $20 \% \mathrm{CD} 11 \mathrm{c}+$. b Top isotype controls using infected cells to adjust gating; middle and bottom analysis of infected non-

properdin-deficient mice, possibly indicative of lysosomal escape of L. monocytogenes (Fig. 5g-1).

Listeriolysin was detected in supernatants of infected splenocytes of wildtype and properdin-deficient mice by Western blot (data not shown). Therefore, to preserve the viability of splenocytes for flow cytometry, heat-killed L. monocytogenes were used. Compared to the wildtype, the dendritic cellenriched population of properdin-deficient bone marrow was impaired in the upregulation of CD40, an accessory molecule needed to prolong contact between antigen-presenting and T cells (Fig. 6). Surface expressions of MHCII, CD80 and CD86 were increased after infection, indicating maturation of cells, but were not appreciably different between the genotypes (Fig. S3). A selective impairment of CD40 upregulation in dendritic cells isolated from properdin-deficient micecontrasting with MHCII, CD80 and CD86-had previously been observed when maturing bone marrow-derived dendritic adherent cells from bone marrow of wildtype and properdin-deficient mice. Numbers indicate geometric means of CD $11 \mathrm{c}+{ }^{+} \mathrm{CD} 40^{+}$events. One of three analyses of infected cells is shown. All are summarised in $\mathbf{c}$

cells from both genotypes with $1 \mu \mathrm{g} / \mathrm{ml}$ LPS E.coli 0111:B4 for $48 \mathrm{~h}$ (N. Salehen, $\mathrm{PhD}$ thesis).

An in vivo model of murine listeriosis reproducibly showed that complement properdin contributed significantly to host survival (Fig. 7a) though the numbers of bacteria retrieved from infected livers were not different between the two genotypes (Fig. 7b). After 2 days, 7/9 wildtype mice and only $2 / 9$ properdin-deficient mice were alive. The IFN $\gamma$ levels in serum were significantly elevated in those mice with worse prognosis, i.e. the L. monocytogenes infected properdin-deficient mice (Fig. 7c). Granuloma formation was not impaired in properdin-deficient mice. The titres of antilisterial IgM tested towards immobilised $L$. monocytogenes were comparable in naïve and infected mice (data not shown).

The host normally responds to infection with $L$. monocytogenes with an increase in IL-17 [33], which aids in the 

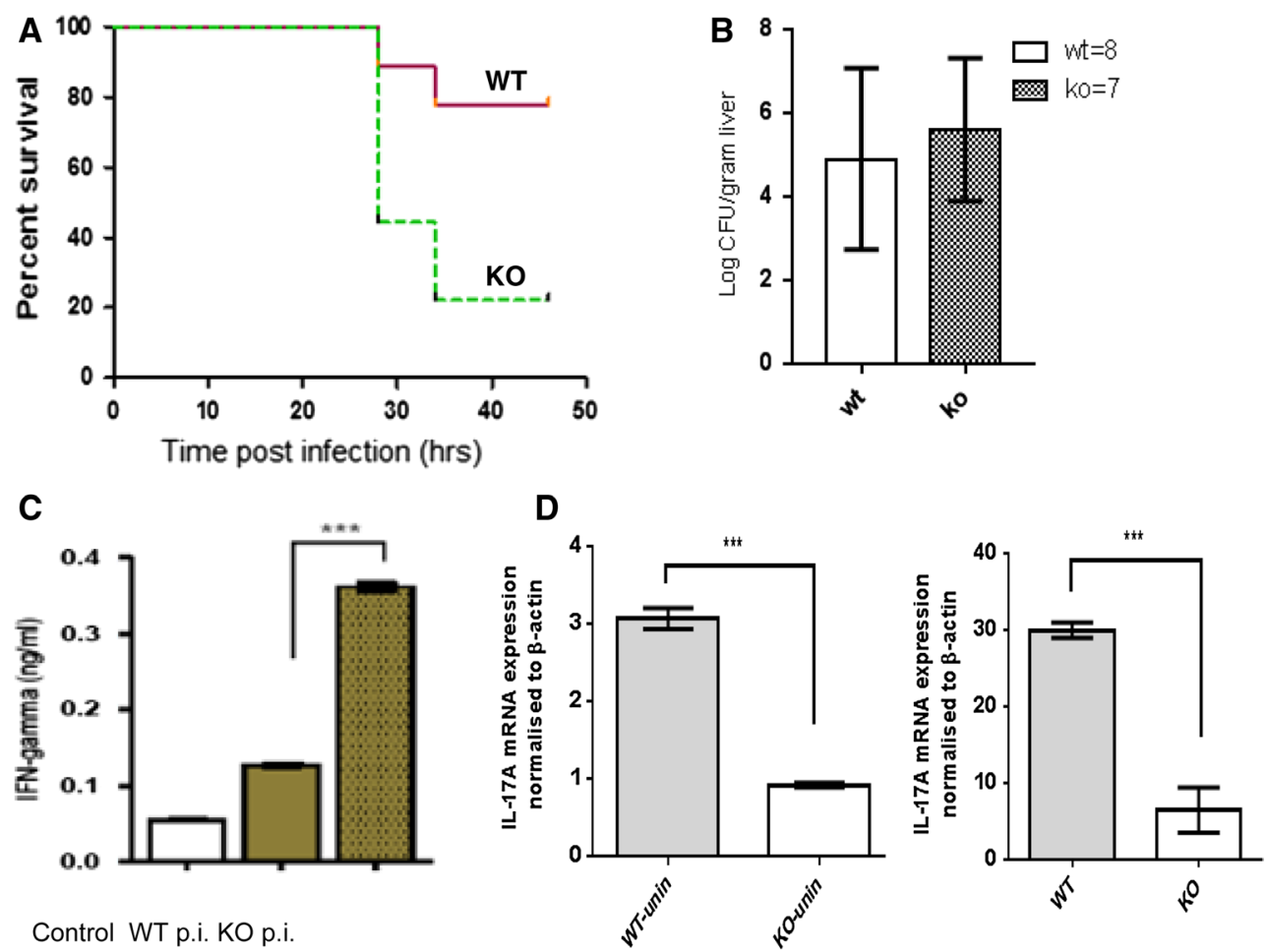

Fig. 7 Properdin-deficient and wildtype mice ( $n=9$ each genotype) were injected with passaged $L$. monocytogenes $\left(1 \times 10 \mathrm{e}^{6}\right)$ and culled at humane endpoint. Survival was plotted against $100 \%$ and was higher in wildtype compared to properdin-deficient mice $(p<0.05$, a viable counts were determined by serial dilution from livers homogenised in PBS; homogenisation in $\mathrm{dH}_{2} \mathrm{O}$ gave the same distribution (b). IFN $\gamma$ was determined by ELISA using sera pooled from mice with identical score of disease severity (lethargic, $n=2$ each genotype $(p<0.0005)$. $\mathbf{c}$ IL-17A mRNA expression was quantified from spleens of uninfected mice $(n=2, p<0.005)$ and of mice of equal severity of listeriosis (hunched, piloerect), culled 29 h p.i. $(n=1$ $\mathrm{WT}, n=2 \mathrm{KO}, p<0.005)$. Note the increased overall abundance of expression in infected mice $(\mathbf{d})$ polarisation of M1 macrophages [34]. The level of complement activity reportedly affects IL-17 production by T cells and macrophages [35]. When investigating the expression levels in control properdin-deficient and wildtype mice, we found significantly impaired basal expression of IL17A mRNA in properdin-deficient mice (Fig. 7d). After infection with $L$. monocytogenes, mice of identical severity culled at $29 \mathrm{~h}$ were analysed for their splenic IL-17A mRNA expression. Properdin-deficient mice were again reduced in their expression by threefold though the overall abundance of mRNA was higher than unstimulated controls (Fig. 7d). In support of this observation, the relative reduction in inflammatory splenic IL-17A mRNA expression in the absence of properdin was also found when analysing mice infected with a lower dose $\left(5 \times 10^{5}\right.$ L. monocytogenes) and survival to $49 \mathrm{~h}(n=4 \mathrm{WT}, n=1 \mathrm{KO})$ (data not shown).

In summary, this part of the study is the first to show that intact complement is essential in survival of murine listeriosis and in sustaining a cellular response to the intracellular pathogen $L$. monocytogenes. In the absence of properdin, the dendritic cell-like cell population derived from bone marrow had reduced numbers of intracellular Listeria compared to cells from wildtype mice and showed impaired maturation to function as antigen-presenting cells. In vivo, properdin-deficient mice had greater disease severity, consistent with impaired M1-type activation, and worse prognosis than wildtype mice.

\section{Discussion}

Our previous work showing opposing survival outcomes of properdin-deficient mice in response to subacute non-septic shock elicited by LPS or zymosan [7] gave support to the notion that the significance of a role of properdin is tailored to the type of stimulation. Subsequent work using models of zymosan-induced arthritis and collagen antibodyinduced arthritis revealed that properdin-deficient mice after intraarticular injection of zymosan showed a Th1 phenotype in regional lymphnodes (resulting in fewer antibodies and more proteoglycan loss in joints) [36], and in the arthritic immune complex disease, less tissue damage was observed, which in part was due to a lack of complement 
amplification, but also due to a cellular phenotype different from wildtype [37]. Because properdin-deficient mice are not deficient in any of the activation pathways, we surmised that the role of properdin in the outcome from inflammation or infection related to the expression of a predominately humoral or cellular phenotype of the immune response.

Our data indicate that properdin-deficient mice polarise macrophages to an M2 phenotype, which subsequently co-determines host outcome following sepsis. The data add to an accumulating string of evidence that complement activation products shape cellular phenotypes [38-44].

Reduced mortality of properdin-deficient mice compared to their colony wildtype controls in a streptococcal pneumonia and sepsis model

Previously, we have shown that properdin-deficient mice generated by site-specific targeting [6] were impaired in their alternative pathway activity [6,7], which led to impaired amplification of the classical pathway of complement activation [36]. Lower levels of C5a in properdindeficient mice $[7,36]$ concur with reduced expression of Fc $\gamma R 2 b$ on phagocytic cells, resulting in cells impaired in their ability to phagocytose-encapsulated microorganisms such as S. pneumoniae [29].

Mice held in specific pathogen-free environments express natural IgM antibodies reactive with capsular polysaccharides, including those specific for $S$. pneumoniae serotype 2 (Fig. 1a). The anticapsular polysaccharide $2 \mathrm{IgM}$ antibody response after immunisation with the polysaccharide pneumococcal vaccine was comparable between properdin-deficient and wildtype mice. Their total IgM levels were not elevated compared to unvaccinated mice. Mice deficient of C3 or CR2 (the B cell complement receptor) were also able to increase their serotype 2 capsular polysaccharide reactive IgM after immunisation [28], negating concerns that a decrease in $\mathrm{C} 3$ fragments would increase the threshold for antibody production [reviewed in [45]]. However, it is worth noting that the immunisations were performed by the i.p. route, stimulating primarily peritoneal B-1-cells [46]. The protective effect of vaccination was tested by i.n. infection with $S$. pneumoniae D39 (serotype 2) and verified for wildtype mice. Properdindeficient mice, however, reproducibly demonstrated a survival advantage in this model—which was inherent—even though the bacterial load in lungs and systemic seeding into the blood at $48 \mathrm{~h}$ post-infection was higher. Their clinical severity scores were significantly better than those obtained for infected wildtype mice.

The increase in serum C3 as an acute phase marker in the inflammatory response showed no difference between the two genotypes. Pulmonary C3 fragments, however, were higher for the infected properdin-deficient group though numbers and location of neutrophils (parenchymal, vascular) were comparable to the infected wildtype group. Given that the bacterial viable count was elevated in lungs of properdin-deficient mice, it is possible that $S$. pneumoniae themselves exerted proteolytic activity against $\mathrm{C} 3$, as shown by others [47].

The survival advantage in the absence of properdin is likely to be determined by the impaired ability to phagocytose $S$. pneumoniae, which we have shown using splenic macrophages, leading to reduced activation of macrophages as measured by their reduced release of the pro-inflammatory cytokine TNF- $\alpha$. These observations are compatible with M2-skewed macrophage activation in the properdin-deficient mice, yielding reduced inflammation and decreased clinical severity. In the septic phase, more IgM is sequestered to the same extent from circulating blood of wildtype and properdin-deficient mice. However, in the absence of the amplification loop of complement, there is no increase of $\mathrm{C} 4 \mathrm{c}$ in serum from properdin-deficient compared to wildtype mice at $48 \mathrm{~h}$ p.i.

Against these novel findings and given that the response towards zymosan, being rich in protein-carbohydrate complexes, also requires natural antibodies [48], the survival advantage of properdin-deficient mice in our zymosan shock model [7] is likely to have been due to a qualitatively different immune response as outlined above, rather than a beneficially impaired inflammatory ability in the absence of properdin.

Reduced survival of properdin-deficient mice compared to their colony wildtype controls in a model of murine listeriosis

To understand the role of properdin in cell-mediated responses during infection with $L$. monocytogenes, we investigated phenotypic changes in differentiated bone marrow cells from properdin-deficient and wildtype mice. When infected with the same MOI, the dendritic cell-like population prepared from properdin-deficient mice had reduced numbers of intracellular bacteria compared to that from wildtype mice. As a consequence, these cells were also impaired in their antigenic maturation compared to those from wildtype mice after infection with live $L$. monocytogenes (lower CD40 expression on $\mathrm{CD} 11 \mathrm{c}^{+}$cells). They did not differ in the expression and maturation-induced upregulation of MHCII, CD80 and CD86, thereby expanding from other work, which concluded that $\mathrm{C} 3$ was not necessary for maturation of dendritic cells in L. monocytogenes infection [39]. CD40, however, was not assessed in these in vitro analyses of dendritic cells from $\mathrm{C} 3$ deficient mice [39]. The substantial impairment of CD40 upregulation 
Fig. 8 Summary of proposed pathomechanisms of disease in properdin-deficient mice

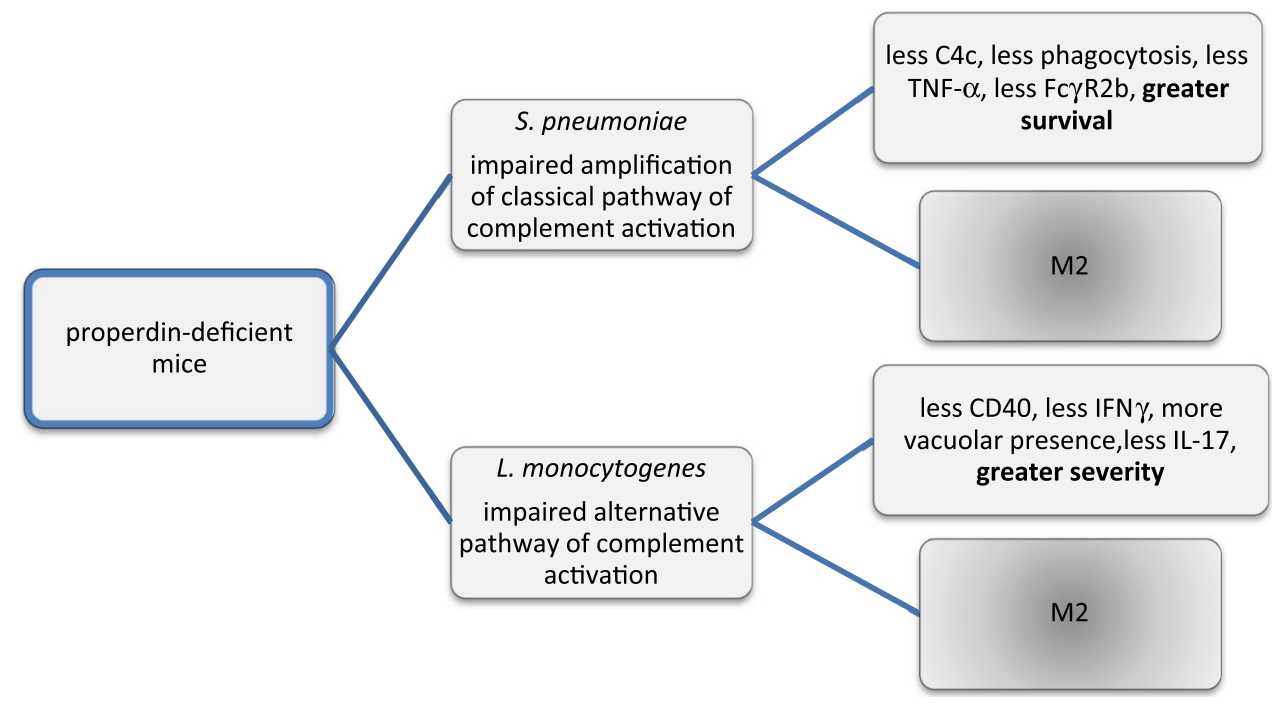

in properdin-deficient $\mathrm{CD} 11 \mathrm{c}^{+}$cells implies less efficient interactions with cognate $\mathrm{T}$ cells. This observation is corroborated by the fact that properdin-deficient mice showed little cytosolic presence of Listeria in their dendritic cell-like population, consistent with impaired cell activation and secretion of IFN $\gamma$ : cytosolic entry of virulent Listeria is required to increase expression of co-stimulatory molecules and to generate an appropriate T-cell response $[49,50]$.

M2-skewed myeloid cells express lower CD40, lower IFN $\gamma$, TNF- $\gamma$ and nitrites than M1-polarised cells [51]; this coincides with lower production of IL-17 [52]. Using these parameters, our study gives consistent evidence that cells isolated from properdin-deficient mice retain in culture a spectrum of activity compatible with M2 polarisation.

IFN $\gamma$ is significantly increased in serum of infected properdin-deficient mice compared to wildtype mice, while both readings were elevated compared to serum from naïve mice. Given that the two genotypes exhibited equal numbers of viable counts in liver homogenates during listeriosis, the increase in IFN $\gamma$ was likely to be the attempt of properdin-deficient mice to counteract M2-type activity, which is detrimental in listeriosis [53].

Taken together, the juxtaposed studies demonstrate that in the attempt to understand the opposing clinical outcomes of the infection models used, a role of properdin deficiency in M2 skewing has been uncovered (Fig. 8). Some determinants of outcome for properdin-deficient mice described for the listeriosis model are likely to have a role in the pneumococcal model via their contribution to M2 skewing, such as IL-17 [54]. Conversely, in wildtype mice, we now conclude that properdin plays a role in maintaining the M1 phenotype favoured by the genetic background of $\mathrm{C} 57 \mathrm{Bl} / 6$. Given that there is accumulating literature on a role for complement in cellular immune responses, it follows that the findings presented herein pose relevant considerations in the design of complement targeting biomolecules in general and of properdin blockers in particular.

Finally, though the studies presented herein have advanced the appreciation of the crosstalking role of complement in vivo, ex vivo and in vitro, one relevant contributor to the host response could not be analysed; to profile the virulence of $S$. pneumoniae and L. monocytogenes in blood and tissues, an expansion in bacterial growth medium was needed, which provokes another environmental adjustment of the transcriptomes. It is important to recognise that because the pathogens are exposed to selection pressures, which are modulated in the gene-targeted experimental animal, the pathogens are likely to be phenotypically different between the mouse genotypes and therefore are likely to differentially co-determine the infection outcomes in these models. The extent of this contribution is currently under investigation.

Acknowledgments The analysis of the properdin-deficient mice in the streptococcal infection model was partly funded by the MRC (G0400300, CS); A. Dupont was recipient of a College funded PhD studentship. We thank Professor R Camp (University of Leicester) for helpful discussions. Claudia Dembek (Ludwig-Maximilians-University, Munich, Germany) and Nina Lapke (Bernhard Nocht Institute of Tropical Medicine, Hamburg, Germany) are acknowledged for their roles in pilot work. Ken White and Hannah Cragg from the Division of Biomedical Sciences (University of Leicester) are acknowledged for their help with in vivo experimentation and colony maintenance, respectively. Stefan Hyman and Natalie Allcock from the Electron Microscopy Unit (University of Leicester) are acknowledged for their expertise. This publication contains parts of the theses of Aline Dupont (Properdin in immunity-in vitro and in vivo investigations, 2008), Nur'Ain Salehen (The role of properdin in cellular and humoral responses-in vitro and in vivo analyses, 2011) and Fatima Mohamed (The role of properdin in murine infection with Listeria monocytogenes, 2013), University of Leicester. 


\section{Conflict of interest None.}

Open Access This article is distributed under the terms of the Creative Commons Attribution License which permits any use, distribution, and reproduction in any medium, provided the original author(s) and the source are credited.

\section{References}

1. Garlatti V, Chouquet A, Lunardi T, Vivès R, Païdassi H, LortatJacob H, Thielens NM, Arlaud GJ, Gaboriaud C (2010) Cutting edge: $\mathrm{C} 1 \mathrm{q}$ binds deoxyribose and heparan sulfate through neighboring sites of its recognition domain. J Immunol. 185:808-812

2. Sim RB, Wallis R (2011) Surface properties: immune attack on nanoparticles. Nat Nanotechnol 6:80-81. doi:10.1038/nn ano.2011.4

3. Nickel KF, Renné T (2012) Crosstalk of the plasma contact system with bacteria. Thromb Res 130(Suppl 1):S78-S83. doi:10.1016/j.thromres.2012.08.284

4. Oikonomopoulou K, Ricklin D, Ward PA, Lambris JD (2012) Interactions between coagulation and complement - their role in inflammation. Semin Immunopathol. 34:151-165. doi:10.1007/ s00281-011-0280-x

5. Bánki Z, Posch W, Ejaz A, Oberhauser V, Willey S, Gassner C, Stoiber H, Dittmer U, Dierich MP, Hasenkrug KJ, Wilflingseder D (2010) Complement as an endogenous adjuvant for dendritic cell-mediated induction of retrovirus-specific CTLs. PLoS Pathog 6(e1000891):1000. doi:10.1371/journal.ppat891

6. Stover CM, Luckett JC, Echtenacher B, Dupont A, Figgitt SE, Brown J, Männel DN, Schwaeble WJ (2008) Properdin plays a protective role in polymicrobial septic peritonitis. J Immunol. 180:3313-3318

7. Ivanovska ND, Dimitrova PA, Luckett JC, El-Rachkidy Lonnen R, Schwaeble WJ, Stover CM (2008) Properdin deficiency in murine models of nonseptic shock. J Immunol 180:6962-6969

8. Späth PJ, Sjöholm AG, Fredrikson GN, Misiano G, Scherz R, Schaad UB, Uhring-Lambert B, Hauptmann G, Westberg J, Uhlén M, Wadelius C, Truedsson L (1999) Properdin deficiency in a large Swiss family: identification of a stop codon in the properdin gene, and association of meningococcal disease with lack of the IgG2 allotype marker G2 m(n). Clin Exp Immunol 118:278-284

9. Toropainen M, Saarinen L, Wedege E, Bolstad K, Michaelsen TE, Aase A, Käyhty H (2005) Protection by natural human immunoglobulin M antibody to meningococcal serogroup B capsular polysaccharide in the infant rat protection assay is independent of complement-mediated bacterial lysis. Infect Immun 73:4694-4703

10. Brown JS, Hussell T, Gilliland S, Holden DW, Paton JC, Ehrenstein M, Walport M, Botto M (2002) The classical pathway is the dominant complement pathway required for innate immunity to Streptococcus pneumoniae infection in mice. Proc Natl Acad Sci USA 99:16969-16974

11. Ali YM, Lynch NJ, Haleem KS, Fujita T, Endo Y, Hansen S, Holmskov U, Takahashi K, Stahl GL, Dudler T, Girija UV, Wallis R, Kadioglu A, Stover CM, Andrew PW, Schwaeble WJ (2012) The lectin pathway of complement activation is a critical component of the innate immune response to pneumococcal infection. PLoS Pathog 8:e1002793. doi:10.1371/journal.ppat.1002793

12. Endo Y, Takahashi M, Iwaki D, Ishida Y, Nakazawa N, Kodama T, Matsuzaka T, Kanno K, Liu Y, Tsuchiya K, Kawamura I, Ikawa M, Waguri S, Wada I, Matsushita M, Schwaeble WJ, Fujita $\mathrm{T}$ (2012) Mice deficient in ficolin, a lectin complement pathway recognition molecule, are susceptible to Streptococcus pneumoniae infection. J Immunol. 189:5860-5866. doi:10.4049/jimmu nol.1200836
13. Kerr A, Paterson G, Riboldi-Tunnicliffe A, Mitchell T (2005) Innate immune defense against pneumococcal pneumonia requires pulmonary complement component C3. Infect Immun 73:4245-4252

14. Croize J, Arvieux J, Berche P, Colomb MG (1993) Activation of the human complement alternative pathway by Listeria monocytogenes: evidence for direct binding and proteolysis of the $\mathrm{C} 3$ component on bacteria. Infect Immun 61:5134-5139

15. Petit JC (1980) Resistance to listeriosis in mice that are deficient in the fifth component of complement. Infect Immun 27:61-67

16. Gervais F, Desforges C, Skamene E (1989) The C5-sufficient A/J congenic mouse strain. Inflammatory response and resistance to Listeria monocytogenes. J Immunol. 142:2057-2060

17. Helmy KY, Katschke KJ Jr, Gorgani NN, Kljavin NM, Elliott JM, Diehl L, Scales SJ, Ghilardi N, van Lookeren Campagne M (2006) CRIg: a macrophage complement receptor required for phagocytosis of circulating pathogens. Cell 124:915-927

18. Rosen H, Gordon S, North R (1989) Exacerbation of murine listeriosis by a monoclonal antibody specific for the type 3 complement receptor of myelomonocytic cells. Absence of monocytes at infective foci allows Listeria to multiply in nonphagocytic cells. J Exp Med 170:27-37

19. Conlan JW, North RJ (1992) Monoclonal antibody NIMP-R10 directed against the $\mathrm{CD} 11 \mathrm{~b}$ chain of the type 3 complement receptor can substitute for monoclonal antibody 5C6 to exacerbate listeriosis by preventing the focusing of myelomonocytic cells at infectious foci in the liver. J Leukoc Biol 52:130-132

20. Mielke ME, Rosen H, Brocke S, Peters C, Hahn H (1992) Protective immunity and granuloma formation are mediated by two distinct tumor necrosis factor alpha- and gamma interferondependent $\mathrm{T}$ cell-phagocyte interactions in murine listeriosis: dissociation on the basis of phagocyte adhesion mechanisms. Infect Immun 60:1875-1882

21. Briles DE, Forman C, Hudak S, Claflin JL (1982) Anti-phosphorylcholine antibodies of the T15 idiotype are optimally protective against Streptococcus pneumoniae. J Exp Med 156:1177-1185

22. Garifulin O, Boyartchuk V (2005) Listeria monocytogenes as a probe of immune function. Brief Funct Genomic Proteomic. 4:258-269

23. Sen G, Khan AQ, Chen Q, Snapper CM (2005) In vivo humoral immune responses to isolated pneumococcal polysaccharides are dependent on the presence of associated TLR ligands. J Immunol. 175:3084-3091

24. Wernette CM, Frasch CE, Madore D, Carlone G, Goldblatt D, Plikaytis B, Benjamin W, Quataert SA, Hildreth S, Sikkema DJ, Käyhty H, Jonsdottir I, Nahm MH (2003) Enzyme-linked immunosorbent assay for quantitation of human antibodies to pneumococcal polysaccharides. Clin Diagn Lab Immunol 10:514-519

25. Wenderfer SE, Soimo K, Wetsel RA, Braun MC (2007) Analysis of $\mathrm{C} 4$ and the $\mathrm{C} 4$ binding protein in the MRL/lpr mouse. Arthritis Res Ther. 9:R114

26. Westcott MM, Henry CJ, Cook AS, Grant KW, Hiltbold EM (2007) Differential susceptibility of bone marrow-derived dendritic cells and macrophages to productive infection with Listeria monocytogenes. Cell Microbiol 9:1397-1411

27. Figueroa J, Andreoni J, Densen P (1993) Complement deficiency states and meningococcal disease. Immunol Res 12:295-311

28. Jones HE, Taylor PR, McGreal E, Zamze S, Wong SY (2009) The contribution of naturally occurring IgM antibodies, IgM cross-reactivity and complement dependency in murine humoral responses to pneumococcal capsular polysaccharides. Vaccine. 27:5806-5815. doi:10.1016/j.vaccine.2009.07.063

29. Clatworthy MR, Smith KG (2004) FcgammaRIlb balances efficient pathogen clearance and the cytokine-mediated consequences of sepsis. J Exp Med 199:717-723

30. Atkinson JP (2006) C5a and Fcgamma receptors: a mutual admiration society. J Clin Invest. 116:304-306. doi:10.1172/JCI27759 
31. Konrad S, Engling L, Schmidt RE, Gessner JE (2007) Characterization of the murine IgG Fc receptor III and IIB gene promoters: a single two-nucleotide difference determines their inverse responsiveness to C5a. J Biol Chem 282:37906-37912

32. Verschoor A, Neuenhahn M, Navarini AA, Graef P, Plaumann A, Seidlmeier A, Nieswandt B, Massberg S, Zinkernagel RM, Hengartner H, Busch DH (2011) A platelet-mediated system for shuttling blood-borne bacteria to CD $8 \alpha+$ dendritic cells depends on glycoprotein GPIb and complement C3. Nat Immunol 12:11941201. doi: $10.1038 /$ ni.2140

33. Hamada S, Umemura M, Shiono T, Tanaka K, Yahagi A, Begum MD, Oshiro K, Okamoto Y, Watanabe H, Kawakami K, Roark C, Born WK, O’Brien R, Ikuta K, Ishikawa H, Nakae S, Iwakura Y, Ohta T, Matsuzaki G (2008) IL-17A produced by gammadelta $\mathrm{T}$ cells plays a critical role in innate immunity against listeria monocytogenes infection in the liver. J Immunol. 181:3456-3463

34. Zhang Q, Atsuta I, Liu S, Chen C, Shi S, Shi S, Le AD (2013) IL17-Mediated M1/M2 macrophage alteration contributes to pathogenesis of bisphosphonate-related osteonecrosis of the jaws. Clin Cancer Res. doi:10.1158/1078-0432.CCR-13-0042

35. Grailer JJ, Bosmann M, Ward PA (2012) Regulatory effects of C5a on IL-17A, IL-17F, and IL-23. Front Immunol 3:387. doi:10. 3389/fimmu.2012.00387

36. Dimitrova P, Ivanovska N, Schwaeble W, Gyurkovska V, Stover C (2010) The role of properdin in murine zymosan-induced arthritis. Mol Immunol 47:1458-1466. doi:10.1016/j.molimm. 2010.02.007

37. Dimitrova P, Ivanovska N, Belenska L, Milanova V, Schwaeble W, Stover C (2012) Abrogated RANKL expression in properdindeficient mice is associated with better outcome from collagenantibody-induced arthritis. Arthritis Res Ther. 14:R173

38. Moulton RA, Mashruwala MA, Smith AK, Lindsey DR, Wetsel RA, Haviland DL, Hunter RL, Jagannath C (2007) Complement C5a anaphylatoxin is an innate determinant of dendritic cellinduced Th1 immunity to Mycobacterium bovis BCG infection in mice. J Leukoc Biol 82:956-967

39. Nakayama Y, Kim SI, Kim EH, Lambris JD, Sandor M, Suresh $\mathrm{M}$ (2009) $\mathrm{C} 3$ promotes expansion of $\mathrm{CD}^{+}$and $\mathrm{CD} 4^{+} \mathrm{T}$ cells in a Listeria monocytogenes infection. J Immunol 183:2921-2931. doi:10.4049/jimmunol.0801191

40. Dunkelberger JR, Song WC (2010) Role and mechanism of action of complement in regulating T cell immunity. Mol Immunol 47:2176-2186. doi:10.1016/j.molimm.2010.05.008

41. Weaver DJ Jr, Reis ES, Pandey MK, Köhl G, Harris N, Gerard C, Köhl J (2010) C5a receptor-deficient dendritic cells promote induction of Treg and Th17 cells. Eur J Immunol 40:710-721. doi :10.1002/eji.200939333

42. Xu R, Wang R, Han G, Wang J, Chen G, Wang L, Li X, Guo R, Shen B, Li Y (2010) Complement C5a regulates IL-17 by affecting the crosstalk between DC and gd T cells in CLP-induced sepsis. Eur J Immunol 40:1079-1088. doi:10.1002/eji.200940015

43. Purwar R, Bäumer W, Niebuhr M, Tschernig T, Kietzmann M, Werfel T (2011) A protective role of complement component 3 in T cell-mediated skin inflammation. Exp Dermatol 20(9):709714. doi:10.1111/j.1600-0625.2011.01295.x

44. Kemper C, Köhl J (2013) Novel roles for complement receptors in $\mathrm{T}$ cell regulation and beyond. Mol Immunol 56(3):181-190. doi:10.1016/j.molimm.2013.05.223

45. Salehen N, Stover C (2008) The role of complement in the success of vaccination with conjugated vs. unconjugated polysaccharide antigen. Vaccine. 26:451-459

46. Hardy RR (2006) B-1 B cell development. J Immunol. 177: 2749-2754

47. Angel CS, Ruzek M, Hostetter MK (1994) Degradation of C3 by Streptococcus pneumoniae. J Infect Dis 170:600-608

48. von Asmuth EJ, Maessen JG, van der Linden CJ, Buurman WA (1990) Tumour necrosis factor alpha (TNF-alpha) and interleukin 6 in a zymosan-induced shock model. Scand J Immunol 32:313-319

49. Brzoza KL, Rockel AB, Hiltbold EM (2004) Cytoplasmic entry of Listeria monocytogenes enhances dendritic cell maturation and T cell differentiation and function. J Immunol. 173:2641-2651

50. Bahjat KS, Liu W, Lemmens EE, Schoenberger SP, Portnoy DA, Dubensky TW Jr, Brockstedt DG (2006) Cytosolic entry controls CD8+ -T-cell potency during bacterial infection. Infect Immun 74:6387-6397

51. Lolmede K, Campana L, Vezzoli M, Bosurgi L, Tonlorenzi R, Clementi E, Bianchi ME, Cossu G, Manfredi AA, Brunelli S, Rovere-Querini P (2009) Inflammatory and alternatively activated human macrophages attract vessel-associated stem cells, relying on separate HMGB1- and MMP-9-dependent pathways. J Leukoc Biol 85:779-787. doi:10.1189/jlb.0908579

52. Sica A, Mantovani A (2012) Macrophage plasticity and polarization: in vivo veritas. J Clin Invest. 122:787-795. doi:10.1172/JCI59643

53. Benoit M, Desnues B, Mege JL (2008) Macrophage polarization in bacterial infections. J Immunol. 181:3733-3739

54. Fernandes BF, Rezende AB, Alves CC, Teixeira FM, Farias RE, Ferreira AP, Teixeira HC (2010) Splenic autotransplantation restores IL-17 production and antibody response to Streptococcus pneumoniae in splenectomized mice. Transpl Immunol 22:195197. doi:10.1016/j.trim.2009.12.002 